\title{
EVALUASI DIMENSI SALURAN DRAINASE KAWASAN PERMUKIMAN KECAMATAN JAKABARING KOTA PALEMBANG
}

\author{
Ligal Sebastian \\ Dosen Tetap YPTP pada Program Studi Teknik Sipil Fakultas Teknik Universitas Palembang \\ e-mail : ligal.oke@gmail.com
}

\begin{abstract}
ABSTRAK
Kecamatan Jakabaring Kota Palembang memiliki luas sekitar $18,93 \mathrm{Km}^{2}$ merupakan daerah tangkapan air hujan untuk penampungan alami. Seiring dengan bertambahnya penduduk dan pertumbuhan ekonomi, telah mengalami perubahan penggunaan tata guna lahan menjadi area permukiman dan pengembangan kota. Berdasakan data guna lahan pada awalnya di wilayah Jakabaring sebagian besar terdiri dari lahan rawa, dan berada dalam Kawasan daerah aliran sungai (DAS) Musi dalam Sub DAS Jakabaring yang memiliki luas $12,41 \mathrm{Km}^{2}$. Kondisi demikian menyebabkan pada saat musim penghujan dengan curah hujan yang cukup tinggi berpotensi terjadinya genangan atau banjir, sehingga membutuhkan sistem saluran drainase yang baik. Penelitian ini dilakukan secara purposive sampling melalui pengukuran lapangan dan analisa kondisi saluran (data hidrologi dan hidrolika) pada dua lokasi permukiman di perumahan Amin Mulia dan Dekrasnada. Hasil Analisa dan evaluasi terhadap kondisi saluran dilapangan menunjukkan nilai debit rencana $\left(\mathrm{Q}_{\mathrm{p}}\right)=0,076 \mathrm{~m}^{3} /$ detik dan nilai debit aliran didalam saluran $\left(\mathrm{Q}_{\mathrm{r}}\right)=3,387 \mathrm{~m}^{3} /$ detik, dimana nilai $\mathrm{Q}_{\mathrm{p}}<\mathrm{Q}_{\mathrm{r}}$, sehingga tidak perlu dilakukan perencanaan ulang karena debit aliran didalam saluran sudah dapat ditampung oleh dimensi saluran yang ada dan relatif sudah memenuhi standar.
\end{abstract}

Kata Kunci : Subdas Jakabaring, Saluran Drainase, Debit saluran

\section{PENDAHULUAN}

Kawasan Jakabaring merupakan kawasan tangkapan air hujan sebagai area penampungan alami, namun sejalan perkembangannya mengalami perubahan penggunaan tata guna lahan mengalami pengembangan kota berupa fasilitas public, permukiman dan perkantoran. Kondisi tofografi yang merupakan area dataran rendah berfungsi sebaai kawasan tangkapan air telah beralih fungsi menjadi daerah pemukiman dan perdagangan.

Jakabaring sendiri merupakan daerah yang terletak di Daerah Aliran Sungai (DAS) yaitu sungai Musi dan juga memiliki Sub DAS yang tersebar di lokasi Jakabaring. Seiring berjalannya waktu perubahan yang terjadi pada Sub DAS

Jakabaring tersebut dapat mengakibatkan ketidakseimbangan hidrologi dan berpengaruh negatif pada kondisi DAS. Sistem drainase yang tidak berfungsi secara efektif pada akhirnya akan menyebabkan terjadinya banjir atau genangan yang berpengaruh terjadinya kerusakan-kerusakan pada permukaan atau ruas jalan. Ruas jalan yang tergenang air secara intensif akan menyebabkan material yang digunakan tidak dapat bertahan lama. Ruas jalan yang mengalami kerusakan merupakan salah satu permasalahan yang sangat krusial yang diakibatkan oleh sistem drainase. Oleh karena itu penelitian ini dilakukan untuk mengevaluasi dan Analisa terhadap penampang saluran drainase terbuka yang memenuhi standar dan sesuai dengan topografi wilayah Kawasan Permukiman khususnya di perumahan Amin Mulia dan perumahan Dekrasnada Kelurahan 15 Ulu kecamatan Jakabaring Kota Palembang. Merujuk fenomena dan potensi permasalahan yang di uraikan diatas, maka diperlukan upaya melalui evaluasi perencanaan dimensi saluran drainase terbuka yang sesuai topografi wilayah Kawasan sebagai upaya 
pencegahan dan pengendalian banjir atau genangan yang dapat terjadi.

\section{LANDASAN TEORI \\ 1. Saluran Drainase}

Drainase berasal dari bahasa Inggris yaitu drainage yang mempunyai arti mengalirkan, menguras, membuang, mengalihkan air, atau mengeringkan suatu wilayah tertentu dari genangan air. Sebagai media untuk mengalirkan air disebut saluran drainase yaitu salah satu upaya teknis pembuangan air untuk mengurangi kelebihan air yang berasal dari air hujan, rembesan, dan kelebihan air irigasi dari suatu kawasan atau lahan. Jika penanganan drainase kurang baik, maka akan mengakibatkan tergenangnya lingkungan sekitar saluran drainase yang pada akhirnya menyebabkan kerusakan.Fungsi drainase yaitu membuang air di atas permukaan tanah yang berlebihan atau menurunkan atau menjaga muka air tanah agar tidak terjadi genangan(Soehardjono, 1984).Selain itu, membebaskan suatu wilayah, terutama wilayah dengan jumlah kepadatan penduduk yang banyak, dari genangan air, erosi dan banjir, serta berfungsi untuk menciptkan sistem tata guna lahan yang baik yang dapat dioptimalkan dan juga memperkecil kemungkinan kerusakankerusakan struktur tanah untuk jalan dan bangunan lainnya.

Bangunan saluran drainase terdiri dari saluran penerima (interceptor drain), saluran pengumpul (collector drain), saluran pembawa (conveyor drain) saluran induk (maindrain) dan badan air penerima (receivingwater). Disepanjang sistem sering dijumpai bangunan lainnya, seperti goronggorong, siphon, pelimpah, bangunan terjun dan stasiun pompa. (Suripin, 2004). Persyaratan dalam Perencaan drainase harus mempertimbangkan segi kemudahan dan nilai ekonomis terhadap pemeliharaan sistem drainase tersebut. Dalam merencanakan drainase permukaan jalan dilakukan perhitungan debit aliran (Q) perhitungan dimensi serta kemiringan selokan dan gorong-gorong, rumus-rumus, tabel, grafik serta contoh perhitungannya. (SNI 03-3424: Tata Cara Perencanaan Drainase Permukaan Jalan, 1994).

\section{Data Hidrologi}

Data hidrologi merupakan kumpulan keterangan mengenai fenomena hidrologi meliputi besarnya curah hujan, temperatur, penguapan, lamanya penyinaran matahari, kecepatan aliran, konsentrasi sedimen sungai akan selalu berubah terhadap waktu (Soewaro, 1995). Analisis hidrologi pada dasarnya merupakan proses pengolahan data curah hujan, data luas dan bentuk daerah pengaliran (catchment area), data kemiringan lahan/beda tinggi, dan data tata guna lahan yang kesemuanya mempunyai arahan untuk mengetahui besarnya curah hujan rata-rata, koefisien pengaliran, waktu konsentrasi, intensitas curah hujan, dan debit banjir rencana, sehingga melalui analisis ini dapat dilakukan juga proses evaluasi terhadap saluran drainase yang ada (eksisting).

Sementara itu, terkait dengan kondisi pengaliran sungai, maka data berdasarkan hasil Analisis Hidrograf Debit Banjir untuk wilayah Kecamatan Jakabaring masuk dalam Sub DAS Jakabaring yang memiliki luas 12,41 $\mathrm{Km}^{2}$.

\subsection{Curah Hujan}

Hujan merupakan komponen yang penting dalam analisa hidrologi perencanaan debit untuk menentukan dimensi saluran drainase. Penentuan hujan rencana dilakukan dengan analisa frekuensi terhadap data curah hujan tahunan, dengan lama pengamatan 10 tahun. Data hujan yang diperoleh berdasarkan hasil pengamatan Badan Meteorologi, Klimatologi, dan Geofisika (BMKG) Kenten Kota Palembang dari tahun2010-2019.

Dalam ilmu statistik dikenal beberapa macam distribusi frekuensi dan empat jenis distribusi yang banyak digunakan dalam bidang hidrologi adalah Distribusi Normal, Distribusi Log Normal, Distribusi Log Pearson Tipe III, dan Distribusi Gumbel. Dalam statistik dikenal beberapa parameter yang berkaitan dengan analisis data yang meliputi rata-rata, simpangan baku, koefisien variasi, dan koefisien skewnes (kecondongan atau kemencengan). Penentuan distribusi frekuensi curah hujan memiliki syarat kecuali distribusi Log Pearson Tipe III. Syarat penentuan distribusi dapat dilihat pada 
tabel 1.

Tabel 1.Syarat jenisdistribusi

\begin{tabular}{|c|l|l|}
\hline No & Jenis Sebaran & \multicolumn{1}{|c|}{ Syarat } \\
\hline 1 & Normal & $\begin{array}{l}\mathrm{Cs} \approx 0 \\
\mathrm{Ck} \approx 3\end{array}$ \\
\hline 2 & Log Normal & $\mathrm{Cs}=3 \mathrm{Cv} \mathrm{Cs}>0$ \\
\hline 3 & Gumbel & $\begin{array}{l}\mathrm{Cs} \approx 1.130^{6} \\
\mathrm{Cv} \approx 5.4002\end{array}$ \\
\hline 4 & Log Pearson Type III & $\begin{array}{l}\text { Kecuali Syarat } \\
1,2,3\end{array}$ \\
\hline
\end{tabular}

Sumber: Suripin,2004

Berdasarkan tabel 1, penentuan jenis distribusi memiliki syarat dalam penentuannya. Distribusi Normal, Distribusi Log Normal, dan Distribusi Gumbel memiliki syarat berupa nilai $\mathrm{Cs}, \mathrm{Cv}$, dan $\mathrm{Ck}$ sedangkan Distribusi Log Pearson Tipe III tidak memiliki syarat. Pemilihan distribusidalam penelitian ini menggunakan Distribusi Log Pearson Tipe III. Analisa yang digunakan yaitu; Distribusi Log Pearson Type III. Pearson telah mengembangkan serangkaian fungsi probabilitas yang dapat dipakai untuk hampir semua distribusi probabilitas empiris. Tiga parameter penting dalam metode Distribusi Log Pearson Type III, yaitu; Harga ratarata(Y), Simpangan baku(S) dan Koefisien kemencengan $(G)$.

Langkah-langkah pengerjaannya menggunakan metode Distribusi Log Pearson Type III sebaga berikut :

1) Ubah data dalam bentuk logaritmatik $\mathrm{Y}=\log \mathrm{X}$

2) Hitung harga rata-rata dengan persamaan:

$$
\bar{Y}=\sum_{\mathrm{n}}^{\sum_{\mathrm{i}} \log X_{\mathrm{i}}}
$$

3) Hitung harga simpangan baku dengan persamaan:

$$
S=\frac{\sqrt{\sum_{\mathrm{i}}\left(\log \mathrm{X}_{\mathrm{i}}-\log \mathrm{Y}\right)^{2}}}{\underline{\mathrm{n}-1}-}
$$

4) Hitung koefisien kemencengan dengan persamaan:

$$
\mathrm{G}=\frac{\mathrm{i}=1 \mathrm{X}_{\mathrm{T}}=\mathrm{Y}+\mathrm{K} . \mathrm{s}-}{(n-1)(n-2) \mathrm{s}^{3}}
$$

5) Hitung logaritma hujan dengan periode ulang $\mathrm{T}$ dengan persamaan:

$$
n \sum^{\mathrm{n}}\left(\log \mathrm{X}_{\mathrm{i}}-\log \mathrm{Y}\right)^{3}
$$

Keterangan :

$\mathrm{G}=$ Koefisien kemencengan

$\mathrm{X}=$ Nilai yang ditentukan

$\mathrm{X} 1=$ Batas atas koef

$\mathrm{X}_{2}=$ Batas bawah koef. $\mathrm{G}$

$\mathrm{Y}=$ Nilai yang akan ditentukan

$\mathrm{Y}_{1}=$ Batas atas kala ulang

$\mathrm{Y}_{2}=$ Batas bawah kala ulang

$\mathrm{K}=$ Faktorprobabilitas

$\mathrm{X}_{\mathrm{i}}=$ Curah hujan ke-I (mm).

$\mathrm{n}$ = Banyaknya data pengamatan.

$\mathrm{X}_{\mathrm{T}}=$ Faktor frekuensi

$\mathrm{Y}=$ Harga rata-rata curah hujan.

$\mathrm{S}$ = Harga simpangan baku

\subsection{Intensitas CurahHujan}

Intensitas curah hujan adalah besar curah hujan selama satu satuan waktu tertentu. Persamaan umum yang dipergunakan untuk menghitung hubungan antara intensitas hujan $\mathrm{T}$ jam dengan curah hujan maksimum harian menggunakan rumus mononobe sebagai berikut:

$$
\mathrm{l}=\mathrm{l}_{1}+\mathrm{l}_{2}+\mathrm{l}_{3}
$$

Keterangan :

$\mathrm{I}=$ Intensitas curah hujan ( $\mathrm{mm} / \mathrm{jam})$.

$\mathrm{R}_{24}=$ Curah hujan maksimum 24 jam (mm).

$\mathrm{t}=$ Lama waktu hujan(jam).

$\mathrm{T}=$ Waktu mulai hujan (jam).

$t_{c}=$ Waktu konsentrasi hujan (jam).

Dengan menggunakan persamaan diatas intensitas curah hujan untuk berbagai nilai waktu konsentrasi dapat ditentukan dari besar data curah hujan harian (24 jam). 


\section{KoefisienLimpasan}

Limpasan merupakan gabungan antara aliran permukaan, aliran-aliran yang tertunda pada cekungan-cekungan dan aliran permukaan (surface flow). Dalam perencanaan drainase bagian air hujan yang menjadi perhatian adalah aliran permukaan (surface run off), sedangkan pengendalian banjir tidak hanya aliran permukaan tetapi limpasan (run off). Koefisien limpasan tergantung pada sifat dan kondisi lahan. Harga $C$ untuk berbagai tipe tanah dan penggunaan lahandisajikan dalam Tabel 2.3. Sebelum menentukan koefisien pengaliran terlebih dahulu menentukan luas daerah pengaliran dengan persamaan dibawah (Suripin, 2004).

$$
\begin{gathered}
\mathrm{A}=\mathrm{p} \times 1 \\
\mathrm{C}=\frac{\left(\mathrm{C}_{1} \times \mathrm{A}_{1}\right)+\left(\mathrm{C}_{2}+\mathrm{A}_{2}\right)+\left(\mathrm{C}_{3}+\mathrm{A}_{3}\right)}{\mathrm{A}_{1}+\mathrm{A}_{2}+\mathrm{A}_{3}}
\end{gathered}
$$

Keterangan:

$\mathrm{C}=$ Koefisien Pengaliran

$\mathrm{C}_{1}=$ Kondisi jalan

$\mathrm{C}_{2}=$ Kondisi bahu jalan

$\mathrm{C}_{3}=$ Tata guna lahan

$\mathrm{A}=$ Luas daerah pengaliran $\left(\mathrm{m}^{2}\right)$

$1=$ Batas daerah pengaliran

$1_{1}=$ Ditetapkan dari as jalan sampai tepi perkerasan

$1_{2}=$ Ditetapkan dari tepi perkerasan sampai tepi bahu jalan

$1_{3}=$ Tergantung dari keadaan setempat, maksimal $100 \mathrm{~m}$

Tabel 2. Nilai Koefisien Pengaliran

\begin{tabular}{|l|l|l|c|}
\hline No & \multicolumn{1}{|c|}{$\begin{array}{c}\text { Kondisi } \\
\text { Permukaan Tanah }\end{array}$} & $\begin{array}{c}\text { Koefisien } \\
\text { Pengaliran (C) }\end{array}$ & $\begin{array}{c}\text { Faktor } \\
\text { Limpasan }\end{array}$ \\
\hline 1 & BAHAN & & - \\
\hline 2 & Jalan beton \& jalan aspal & $0.70-0.95$ & - \\
\hline 3 & $\begin{array}{l}\text { Jalan kerikil \& jalan } \\
\text { tanah }\end{array}$ & $0.40-0.70$ & \\
\hline & Bahu jalan: & & - \\
\hline & - Tanah berbutir halus & $0.40-0.65$ & - \\
\hline & - Tanah berbutir kasar & $0.10-0.20$ & - \\
\hline & - Batuan masif keras & $0.70-0.80$ & \\
\hline & - Batuan masif lunak & $0.60-0.75$ & \\
\hline
\end{tabular}

Sumber: Suripin, 2004

Keterangan:

\begin{tabular}{|l|l|l|l|}
\hline & TATA GUNA LAHAN & & \\
\hline 1 & Daerah perkotaan & $0.70-0.95$ & 2.0 \\
\hline 2 & Daerah pinggiran kota & $0.60-0.70$ & 1.5 \\
\hline 3 & Daerah industry & $0.60-0.90$ & 1.2 \\
\hline 5 & Permukiman padat & $0.40-0.60$ & 2.0 \\
\hline 6 & Permukiman tidak padat & $0.40-0.60$ & 1.5 \\
\hline 7 & Taman dan kebun & $0.20-0.40$ & 0.2 \\
\hline 8 & Persawahan & $0.40-0.60$ & 0.5 \\
\hline 9 & Perbukitan & $0.70-0.80$ & 0.4 \\
\hline
\end{tabular}

- Hargakoefisienpengaliran(C)untukdaerah datardiambilnilai(C)yeng terkecil dan untuk daerah lereng diambil nilai (C)terbesar.

- Hargafaktorlimpasan(fk)hanyadigunakan untukgunalahansekitarsaluran selain bagianjalan.

\section{Debit Rencana}

Perhitungan debit rencana untuk saluran drainase di daerah perkotaan dapat dilakukan dengan menggunakan rumus Rasional. Debit rencana hendaknya ditetapkan tidak terlalu kecil untuk menjaga agar jangan terlalu sering terjadi ancaman kerusakan bangunan saluran atau daerah sekitarnya oleh potensi kejadian banjir. MetodeRasionaladalah rumusperhitungan debit dengan asumsi yang sederhana. Metode Rasional ini umumnya banyakdigunakan untuk menghitung debit banjirpada daerah aliran sungai yang tidakterlalu luas dengan batasan luas hingga50 $\mathrm{km} 2$, atau tergantung ketersediaanpenyebaran stasiun hujan yang ada padadaerah aliran sungai (Nugroho,2010).Sedangkan Menurut San Diego Country (Ponce, 1989) nilainya berkisar antara 0,65-12,5 km2. Sementara luas wilayah yang digunakan meliputi luas wilayah penelitian berada di Kelurahan 15 Ulu dengan luas sebesar $12 \mathrm{~km} 2$. Persamaan metode Rasional adalah sebagai berikut:

$$
\mathrm{V}_{\text {Sal }}=\underset{\mathrm{n}}{\mathrm{I}} \times \mathrm{R}^{2 / 3} \times \mathrm{S}^{1 / 2}
$$

Keterangan :

$\mathrm{Q}_{\mathrm{p}}=$ Debit rencana $\left(\mathrm{m}^{3} /\right.$ detik $)$.

$\mathrm{C}=$ Koefisien aliran permukaan.

I $=$ Intensitas hujan(mm/jam)

A $=$ Luas DAS $\left(\mathrm{km}^{2}\right)$. 


\section{Kapasitas Saluran}

Kapasitas rencana dari setiap komponen sistem drainase dihitung berdasarkan rumus Manning, yang menjadi dasar dalam menentukan dimensi saluran. Penggunaan persamaan Manning dalam penelian ini selain menentukan kapasitas saluran juga disesuaikan dengan material penyusun saluran drainase. Perbandingan dalam metode ini adalah ketika $\mathrm{Q}_{\mathrm{p}}<\mathrm{Q}_{\mathrm{r}}$ maka debit saluran dapat ditampung oleh dimensi saluran. Adapun persamaannya yaitu sebagai berikut:

$$
\begin{aligned}
& A=b \times m h) h \\
& \hline \underline{R=\frac{A}{P}} \\
& Q_{p}=\text { 0,002778.C.I.A } \\
& Q_{r}=A \times V
\end{aligned}
$$

Keterangan:

$\mathrm{V}_{\text {Sal }}=$ Kecepatan rata-rata aliran saluran(m/detik).

$\mathrm{Q}_{\mathrm{r}}=$ Debit aliran dalam saluran $\left(\mathrm{m}^{3} / \mathrm{det}\right)$.

$\mathrm{n} \quad=$ Koefisien kekasaranManning.

$\mathrm{R}=$ Jari-jari hidrolis (m).

$\mathrm{S}=$ Kemiringan dasar saluran

\begin{tabular}{|c|c|c|}
\hline Saluran & Keterangan & n Manning \\
\hline \multirow{4}{*}{ Tanah } & $\begin{array}{l}\text { Lurus, baru, seragam, landai } \\
\text { dan bersih }\end{array}$ & $0.016-0.033$ \\
\hline & Berkelok, landai dan berumput & $0.023-0.040$ \\
\hline & Tidak terawat dan kotor & $0.050-0.140$ \\
\hline & $\begin{array}{l}\text { Tanah berbatu, kasar, tidak } \\
\text { teratur }\end{array}$ & $0.035-0.045$ \\
\hline \multirow{2}{*}{ pasangan } & Batu kosong & $0,023-0,035$ \\
\hline & Pasangan batu belah & $0,017-0,030$ \\
\hline \multirow[t]{2}{*}{ Beton } & $\begin{array}{l}\text { Halus, sambungan baik dan } \\
\text { rata }\end{array}$ & $0.014-0.018$ \\
\hline & $\begin{array}{l}\text { Kurang halus dan sambungan } \\
\text { kurang rata }\end{array}$ & $0.018-0.030$ \\
\hline
\end{tabular}

A $=$ Luas penampang saluran $\left(\mathrm{m}^{2}\right)$.

$\mathrm{P} \quad=$ Keliling basah saluran $(\mathrm{m})$.

Tabel 3. Angka kekasaran Manning

Sumber: Ven Te Chow, 1992

\section{Faktor-FaktorPenyebab Banjir}

Pada musim hujan bencana alam yang sering terjadi adalah banjir. Banjir merupakan salah satu bencana alam yang sering terjadi di Indonesia, khususnya di Kawasan Permukiman Jakabaring yang terletak di daerah dataran rendah. Penyebab banjir yang terjadi di Permukiman Jakabaring disebabkan oleh beberapa faktor yaitu;

\subsection{Faktor Alam}

Tingginya intensitas hujan yang terjadi di Kota Palembang dan Beberapa Kabupaten lainnya di Sumsel membuat daya tampung saluran drainase di Permukiman Jakabaring tidak dapat menampung debit airhujan yang terun. Air kiriman dari limpasan permukaan berbagai bentuk struksur juga menjadi salah satu faktor penyebab banjir yang terjadi.

\subsection{Faktor Manusia}

Adapun penyebab banjir yang di sebabkan oleh manusia adalah sebagai berikut:

a. Pengalihan fungsi lahan yang awalnya adalah salah satu daerah resapan air hujan menjadi permukuman yang padatpenduduk.

b. Tidak adanya pengendalian sampai dan sedimentasi akibat limpasan permukaan yang menyebabkan sedimen yang dibawa oleh air hujan masuk kedalam saluran darinase. Drainase yang semakin dangkal membuat buangan air hujan dan air limbah rumah tangga naik ke permukaan jalan dan menyebabkan kerusakan di beberapa ruas jalan.

c. Banjir/Genangan yang terjadi di Permukiman Jakabaring akan dominan terjadi pada musim hujan dan hal ini disebabkan oleh perencanaan penampang saluran drainase yang kurang sesuai dengan kondisi tofografi lahan di kawasan Jakabaring.

\section{Drainase MenurutKonstruksi}

Saluran drainase menurut konstruksi, terdiri atas 2 bagian, yaitu terbuka dan tertutup.

a. Saluran terbuka yakni saluran yang 
konstruksi bagian atasnya terbuka dan berhubungan dengan udara luar. Saluran ini lebih sesuai untuk drainase hujan yang terletak di daerah yang mempunyai luasan yang cukup, ataupaun drainase non-hujan yang tidak membahayakan kesehatan/ mengganggu lingkungan.

b. Saluran tertutup yakni saluran yang konstruksi bagian atasnya tertutup dan saluran ini tidak berhubungan dengan udara luar. Saluran ini sering digunakan untuk aliran air kotor atau untuk saluran yang terletak di tengahkota.

\section{Kerangka Penelitian}

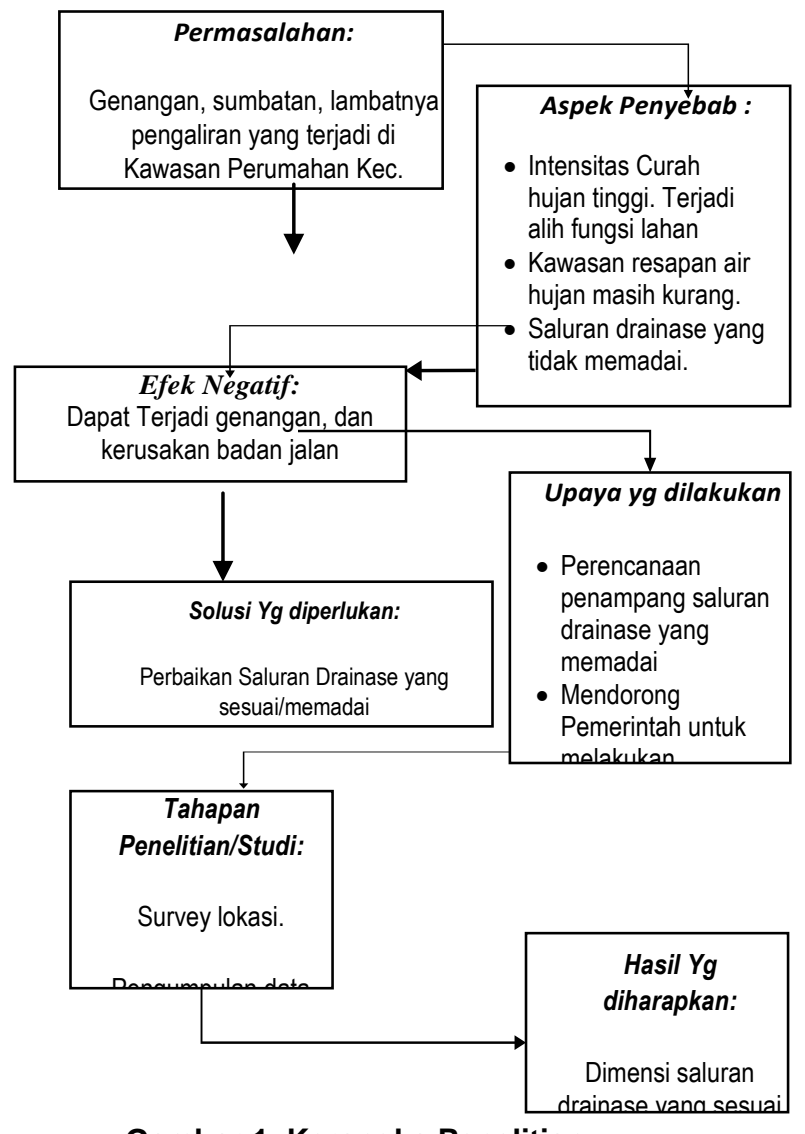

Gambar 1. Kerangka Penelitian

\section{METODOLOGI}

Lokasi Penelitian berada di beberapa kawasan, yaitu Perumahan Top Amin Mulia Jl. Beringin Raya Kelurahan 15 Ulu Kecamatan Jakabaring dan Perumahan Dekranasda Jl. Palem Raya Kelurahan 15 Ulu Kecamatan Jakabaring Kota Palembang. Selain itu, data- data pelengkap di ambil dikantor Badan Meteorologi Klimatologi dan Geofisika (BMKG) Kenten Kota Palembang.

Pengumpulan data dengan survey awal dan tahap lanjutan dengan melakukan pengukuran lapangan terhadap objek saluran drainase eksisting sebagai data eksisting atau pembanding terkait kondisi saluran drainase yang ada. Selanjutnya metode analisa Metode analisa yang digunakan di dalam penelitian ini yaitu analisa hidrologi dan analisa hidrolika. survey lapangan dilakukan dengan tujuan mendata dan melihat kondisi berbagai saluran terbuka/drainase terpilih dengan metode purposive sampling (pemilihan saluran karena pertimbangan tertentu) yang selanjutnya dilakukan pengukuran dan didokumentasi untuk selanjutnya dianalisa dan menjadi rujukan dalam penelitian/perencanaan.

Sementara terkait dataprimer yang digunakan dalam penelitian ini adalah data eksisting hasil pengamatan dan pengukuran saluran drainase terbuka di Kawasan permukiman/Perumahan di Kelurahan 15 Ulu Kecamatan Jakabaring Kota Palembang. Data eksisting saluran terbuka atau drainase merupakan hasil survey dan pengukuran secara langsung di lapangan dengan mengunakan roll meter yaitu lebar, tinggi, dan beda tinggi dasar saluran.

Sementara fokus kegiatan yang dilakukan dalam pengambilan data sekunder adalah

mengumpulkansemuadatayangakandigunaka ndalamanalisisdatadariinstansi terkait, dimana untuk pengambilan data curah hujan tahunan selama 10 tahun sejak 2009 sd 2019 dari Badan Meteorologi Klimatologi dan Geofisika (BMKG) Kenten Kota Palembang, data eksisting drainase, data kondisi elevasi tanah/topografi Kawasan Jakabaring dan kondisi administrasi wilayah kelurahan dan kecamatan. 


\section{Rancangan Penelitian}

Rancangan penelitian yang akan digunakan dalam penelitian ini adalah berupa studi literatur yaitu mempelajari pustaka yang berhubungan dengan pemeliharaan dan perencanaan saluran drainase terbuka dari berbagai sumber seperti berupa literatur buku dan perencanaan, jurnal, maupun data dari internet. Dasar rancangan penelitian yaitu melihat latar belakang berupa permasalahan yang terjadi pasa saluran drainase eksisting dan dikaitkan dengan kejadian genangan/banjir serta membuat asumsi dari dampak dan solusi dimensi saluran yang sesuai kondisi iklim atau hujan yang terjadi di kawasan Kec. Jakabaring.

\section{Analisa Data}

Data yang telah didapatkan dari pengamatan dan survey pengukuran lapangan, data primer dan sekunder, kemudian dilakukan kompilasi, analisis data curah hujan, debit rencana dan deskripsi kondisi eksisting saluran drainase, yaitu kondisi, dimensi saluran drainase yang ada di dua perumahan/pemukiman dalam kawasan Kelurahan 15 Ulu Kecamatan Jakabaring. Adapun metode analisis data yang dilakukan sebagai berikut :

\subsection{Data Curah Hujan}

Data curah hujan diperoleh dari pusat BMKG Kenten Palembang, dimana Data curah hujan yang digunakan adalah kala ulang 10 tahun dari tahun 2010-2019. Dari analisa curah hujan didapatkan data curah hujan wilayah dan kondisi banjir yang berpotensi terjadi di kawasan perumahan lokasi penelitian dan sekitarnya. Sementara analisis frekuensi curah hujan yang digunakan adalah Distribusi Log Pearson Type III.

Untuk mengetahui apakah distribusi Log Pearson Type III yang digunakan dalam perhitungan curah hujan rencana diterima atau ditolak, maka perlu dilakukan uji kecocokan distribusi yang digunakan unruk menguji simpangan secara vertikal apakah distribusi pengamatan dapat diterima secara teoritis. Pengujian yang digunakan adalah Uji Chi Kuadrat dengan menguji penyimpangan distribusi data pengamatan dengan mengukur secara matematis kedekatan antara data pengamatan dan seluruh bagian garis pengamatan distribusi teoritisnya. Ketika perhitungan metode Distribusi LogPearson Type III ditolak maka diubah dengan metode lain, namun ketika metode Distribusi Log Pearson Type III diterima maka dilanjutkan pada perhitungan selanjutnya.

\subsection{Analisa Debit Rencana}

Metode yang digunakan untuk menghitung debit air hujan pada saluran drainase dalam studi ini adalah metode Rasional. Menurut Suripin (2003), metode Rasional adalah salah satu metode yang dianggap baik. Metode ini merupakan salah satu metode yang dikategorikan praktis dalam memperkirakan besarnya debit banjir rencana.

\subsection{Kapasitas Saluran}

Analisis ini dilakukan sebagai kontrol terhadap Perhitungan debit banjir rencana. Dari data-data yang ada dapat dihitung kapasitas maksimum debit saluran terbuka/drainase permukiman Jakabaring dengan menggunakan rumus Manning. Angka kekasaran Manning (n) yang bertujuan untuk menentukan nilai $n$ berdasarkan material yang digunakan untuk membuatsaluran drainase dan mendukung dalam perhitungan dalam perencanaandrainase.

\section{HASIL DAN PEMBAHASAN}

Data yang didapat dari kegiatan survei dan observasi dilokasi eksisting saluran drainase terbuka di lokasi Perumahan Top Amin Mulia Jl. Beringin Raya Kelurahan 15 Ulu Jakabaring dan Perumahan Dekranasda Jl. Palem Raya Kelurahan 15 Ulu Jakabaring Kota Palembang. Data dimensi saluran drainase terbuka Perumahan Top Amin Mulia Jl. Beringin Raya Kelurahan 15 Ulu Kecamatan Jakabaring (Saluran 1) dan Perumahan Dekranasda Jl. Palem Raya Kelurahan 15 Ulu Kecamatan Jakabaring (Saluran 2) sebagai berikut: 


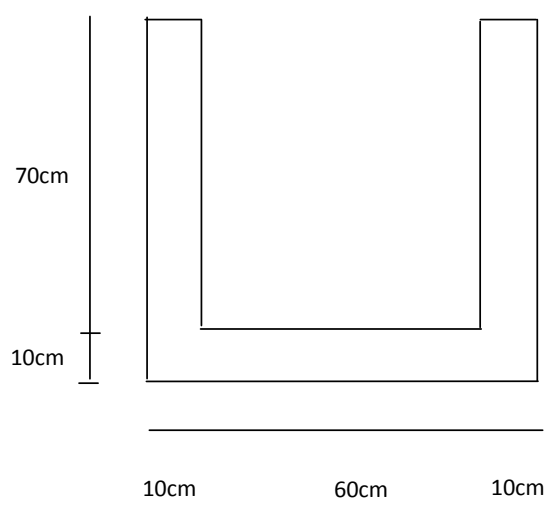

Gambar 2. Penampang Melintang Saluran 1

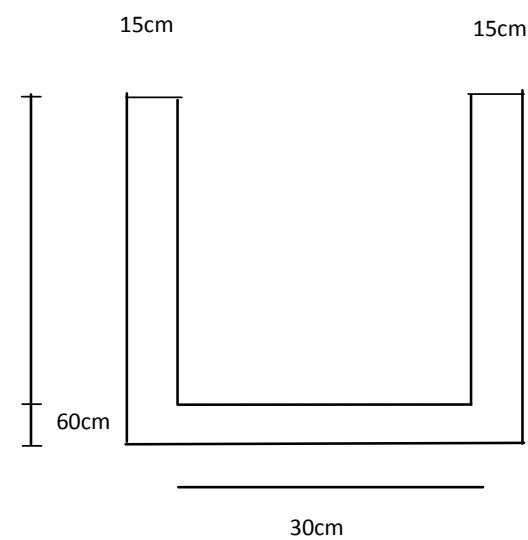

Gambar 3. Penampang Melintang Saluran 2

Data sekunder adalah yang diperoleh dari pihak terkait, yaitu pihak BMKG Kenten Palembang, pihak Kelurahan 15 Ulu, data BPS Kota Palembang dan wawancara singkat dengan warga sekitar perumahan. Data skunder yang digunakan dalam penelitian ini yaitu;

1) Data curah hujan yang didapatkan dari Badan Meteorologi Klimatologi dan Geofisika (BMKG) Kenten Kota Palembang dari tahun 2009-2019. Dapat dilihat pada Lampiran 3.

2) Data luas wilayah Kelurahan 15 Ulu dan Kecamatan Jakabaring yang didapatkan dari Badan Pusat Statistik (BPS) Kota Palembang.

\section{Analisa Data Curah Hujan}

Data curah hujan yang diperoleh dari Badan Meteorologi, Klimatologi dan Geofisika (BMKG) Kenten Palembang berupa data hujan bulanan yang kemudian dianalisis menjadi data curah hujan tahunan maksimum periode 2009 sd 2019. Data hujanmaksimum tersebut diambil dari jumlah curah hujan maksimum pada tiap bulan selama sepuluh tahun. Data hujan maksimum tahunan dapat di lihat pada tabel berikut ini :

Tabel 4. Hujan Tahunan Maksimum Tahun 2009-2019

\begin{tabular}{|c|c|c|}
\hline No & Tahun & $\begin{array}{c}\text { Curah Hujan Maksimum } \\
(\mathbf{R}=\mathbf{m m})\end{array}$ \\
\hline 1 & 2009 & 564,2 \\
\hline 2 & 2010 & 541,70 \\
\hline 3 & 2011 & 392,4 \\
\hline 4 & 2012 & 405 \\
\hline 5 & 2013 & 613 \\
\hline 6 & 2014 & 351 \\
\hline 7 & 2015 & 390,5 \\
\hline 8 & 2016 & 465,7 \\
\hline 9 & 2017 & 406,5 \\
\hline 10 & 2018 & 452,8 \\
\hline 11 & 2019 & 484,6 \\
\hline
\end{tabular}

Sumber : Data BMKG Kenten Palembang, 2020

Data curan maksimum pada tabel 4.1 diatas digunakan untuk memperoleh hujan rata-rata, simpangan baku dan nilai koefisien kemencengan menggunakan metode Log Pearson Tipe III.

\section{Analisa Frek.Curah Hujan}

Analisis frekuensi untuk curah hujan tahunan menggunakan metode Log Pearson Tipe III.

Tabel 5. Pengolahan Data Curah Hujan untuk istribusiLog Pearson Tipe III

\begin{tabular}{|l|l|c|c|c|c|c|}
\hline No & Tahun & $R_{i}$ & $\log R_{i}$ & $\left(\log R_{i}-\log R\right)$ & $\left(\log R_{i}-\log R^{2}\right)^{2}$ & $\log R_{i}-\log R^{3}$ \\
\hline 1 & 2009 & 564,2 & 2,751 & 0,094 & 0,0088 & 0,00083 \\
\hline 2 & 2008 & 541,70 & 2,734 & 0,077 & 0,0059 & 0,00046 \\
\hline 3 & 2009 & 392,4 & 2,594 & $-0,063$ & 0,00397 & $-0,00025$ \\
\hline 4 & 2010 & 405 & 2,607 & $-0,05$ & 0,0025 & $-0,000125$ \\
\hline 5 & 2011 & 613 & 2,787 & 0,13 & 0,0169 & 0,002197 \\
\hline 6 & 2012 & 351 & 2,545 & $-0,112$ & 0,0125 & $-0,00140$ \\
\hline 7 & 2013 & 390,5 & 2,592 & $-0,065$ & 0,0042 & $-0,000274$ \\
\hline 8 & 2014 & 465,7 & 2,668 & 0,011 & 0,0001 & 0,0000013 \\
\hline 9 & 2015 & 406,5 & 2,609 & $-0,048$ & 0,0023 & $-0,000111$ \\
\hline 10 & 2016 & 452,8 & 2,656 & $-0,001$ & 0,0000 & $-0,000000001$ \\
\hline 11 & 2019 & 484,6 & 2,687 & 0,03 & 0,0009 & 0,000027 \\
\hline $\begin{array}{l}2 \\
111\end{array}$ & Jumlah & $\mathbf{5 0 6 7 , 4}$ & $\mathbf{2 9 , 2 3 0}$ & $0,003=0,00$ & 0,0581 & 0,003515 \\
\cline { 2 - 7 } & Rata-rata & 460,673 & 2,657 & 0,00027 & 0,0053 & 0,0003196 \\
\hline
\end{tabular}

Sumber: Olahan data curah Hujan 2021 
Penyelesaian menggunakan metode Log Pearson Tipe III sebagai berikut :

MengubahdatadalambentuklogaritmatikY $=\mathrm{L}$ $\operatorname{ogR} \log 564,2=2,751$

Hitung harga rata-rata:

$\frac{29,230}{11}=2,657$

Hitung harga simapangan baku (S): rumus(2) $\sqrt{ } 0,0581=0,07622 \approx 0,076$

$$
\frac{0581}{11-1}
$$

Hitung koefisien kemencengan (Cs): rumus(3)

$$
\begin{aligned}
\mathrm{Cs} & =\frac{(\log R-\log R)^{3}}{(\mathrm{n}-1)(\mathrm{n}-2) \cdot \mathrm{S}_{\mathrm{x}}} \\
\mathrm{Cs} & =\frac{11 \cdot(0,0035)=}{10.9 \cdot 0,076^{3}}=0,972
\end{aligned}
$$

Nilai koef. kemencengan Cs $=0,972$, maka harga $\mathrm{K}$ untuk periode ulang $\mathrm{T}$ tahun dapat diperoleh dengan interpolasi harga yang terdapat padatabellampiran, selanjutnya, dihitung debit banjir dengan periode ulang $\mathrm{T}$, sebagai berikut :

\subsection{Interpolasi nilai $K$}

Untuk nilai $\mathrm{K}$ diperoleh dimana nilai $\mathrm{Cs}=0,972$, maka pada tabel nilai dengan kala ulang 2 tahun, didapat nilai antara 1,0 dan 0,8 yaitu;

Kala ulang 2 tahun $1,0:-0,164$

$$
0,8:-0,132
$$

Kala ulang 5 tahun 1,0:0,758

$$
0,8: 0,780
$$

Kala ulang 10 tahun $1,0: 1,340$

$$
0,8: 1,336
$$

Kala ulang 25 tahun $1,0: 2,043$

$$
0,8: 1,993
$$

Kala ulang 50 tahun $1,0: 2,542$

$$
0,8: 2,453
$$

Untuk selanjutnya secara interpolasi didapatkan harga $\mathrm{K}$ untuk kala ulanguntuk 2 tahun, untuk 5 tahun, untuk tahun 10 tahun, untuk 25 tahun dan untuk 50 tahun.

\subsection{Uji Kecocokan ChiKuadrat}

Menguji kecocokan suatu distribusi sebaran Distribusi Log Pearson Tipe III data curah hujan, digunakan metode Uji Chi Kuadrat (Chi Square Test). Ditunjukkan dalam tabel sebagai berikut:

Tabel 6

Uji Chi Kuadarat Data Curah Hujan

\begin{tabular}{|c|c|c|c|c|c|}
\hline \multirow{2}{*}{ No } & \multirow{2}{*}{ robabilitas (\%) } & \multicolumn{2}{|c|}{ Jumlah Data } & \multirow{2}{*}{ Oi - Ei } & \multirow{2}{*}{$(\mathbf{O i}-\mathbf{E i})^{2} / \mathbf{E i}$} \\
\cline { 3 - 4 } & & $\mathbf{O i}$ & $\mathbf{E i}$ & & 0,291 \\
\hline 1 & $350<\mathrm{X}<400$ & 3 & 2.2 & 0.8 & 0,018 \\
\hline 2 & $400<\mathrm{X}<450$ & 2 & 2.2 & -0.2 & 0.291 \\
\hline 3 & $450<\mathrm{X}<500$ & 3 & 2.2 & 0.8 & 0,655 \\
\hline 4 & $500<\mathrm{X}<550$ & 1 & 2.2 & -1.2 & 0,018 \\
\hline 5 & $>550$ & 2 & 2.2 & -0.2 & 1,273 \\
\hline & Jumlah & 11 & 11 & 0 & \\
\hline
\end{tabular}

hasil perhitungan yang telah dilakukan didapatkan hasil $X^{2}=1,273<X h^{2}=7,815$ dengan drajat kepercayaannya $(\alpha=5 \%)$ maka data dapat diterima.

\subsection{Koefisien Pengaliran}

Daerah pengaliran dapat diketahui berdasarkan luas daerah pengaliran (A) dan penentuan koefisien pengaliran (C) berdasarkan topografi wilayah Kecamatan Jakabaring Kota Palembang. Kondisi lahan dan tofografi dengan kontur relative rendah dapat mempengaruhi proses pengaliran air hujan atau air permukaan. Kondisi ini sedikit banyak terjadi dikawasan Kecamatan Jakabaring.

Perhitungan koefisien pengaliran diperoleh sebagai berikut:

a. Menentukan luas daerah pengaliran pada daerahpengalirandapatdilihatpada(Lampir an7) yaitu Luasan $(\mathrm{A})=(\mathrm{p})$ saluran xlebar

b. Menentukan luas daerah pengaliran pada daerahpengalirandapatdilihatpada(Lampir an7) yaitu Luasan $(\mathrm{A})=(\mathrm{p})$ saluran xlebar

Tabel 7 Luas Daerah Pengaliran

\begin{tabular}{|c|l|l|}
\hline No & Keterangan $(\mathbf{p} \times \mathbf{I})$ & $\begin{array}{l}\text { Luas } \\
\left(\mathbf{m}^{2}\right)\end{array}$ \\
\hline 1 & Luas badan jalan $\left(\mathrm{A}_{1}\right): 150 \times 2,5$ & $375 \mathrm{~m}^{2}$ \\
\hline 2 & Luas bahu jalan $\left(\mathrm{A}_{2}\right): 150 \times 2,0$ & $300 \mathrm{~m}^{2}$ \\
\hline 3 & Luas Perumahan $\left(\mathrm{A}_{3}\right): 150 \times 30$ & $4.500 \mathrm{~m}^{2}$ \\
\hline \multicolumn{2}{|l|}{} & $5.175 \mathrm{~m}^{2}$ \\
\hline
\end{tabular}

Menentukan nilai Koefisen limpasan rata-rata (C) berdasarkan topografi seperti tabel 2.3 


$$
\begin{aligned}
& C=\frac{C_{1} \cdot A_{1}+C_{2} \cdot A_{2}+C_{3} \cdot A_{3}}{A} \\
& C=\frac{0,9 \cdot 375+0,4 \cdot 300+0,5 \cdot 4500}{5175}=0,523
\end{aligned}
$$

\subsection{Analisis Debit Rencana}

Metode untuk memperkirakan laju aliran permukaan dapat dihitung berdasarkan Intensitas hujan rencana yaitu:

(I) $=105,99 \mathrm{~mm} / \mathrm{jam}$

$=105,99.10^{-3} \mathrm{~m} / 36.10^{2} \mathrm{dt}$

$=2,94 \times 10^{-5} \mathrm{~m} / \mathrm{dt}$

$$
\mathrm{V}_{\text {Sal }}=\underset{\mathrm{n}}{\mathrm{I}} \times \mathrm{R}^{2 / 3} \times \mathrm{S}^{1 / 2}
$$

Maka debit limpasan, yaitu:

$Q=C \cdot I \cdot A$

$=0,5 \times 2,94 \cdot 10^{-5} \times 5175$

$=0,076 \mathrm{~m}^{3} / \mathrm{dt}$

Setelah dilakukan analisis mengenai data curah hujan didapatkan debit rencana $\mathrm{Q}_{\mathrm{p}}=$ $0,076 \mathrm{~m}^{3} /$ detik.

\subsection{Kapasitas Saluran}

Kapasitas rencana dari setiap komponen sistem drainase dihitung berdasarkan rumus Manning, yang merupakan dasar dalam menentukan dimensi saluran. Menentukan luas penampang basah dan keliling basah sesuai dengan dimensi saluran drainase perumahan Amin Mulia TOP Jakabaring Palembang. Menghitung luas penampang basah;

$$
\mathrm{A}=(\mathrm{b} \times \mathrm{mh}) \mathrm{h}
$$

$\mathrm{A}=(0,60+(0,2.0,70)) 0,70$

$\mathrm{A}=0,518 \mathrm{~m}^{2}$

Menghitung keliling basah ;

$$
\begin{aligned}
& P=b+2 h \sqrt{ } m^{2}+1 \\
& P=0,60+2 \cdot 0,70 \sqrt{0,2^{2}+1} \\
& P=2,03 \mathrm{~m}
\end{aligned}
$$

Menghitung jari-jari hidrolis sesuai ;

$$
\mathrm{R}=\frac{\mathrm{A}}{\mathrm{P}}
$$

$\mathrm{R}=\frac{0,518}{2,03}=0,26 \mathrm{~m}$

Menghitung kecepatan rata-rata aliran didalam saluran ;

$\mathrm{V}=\frac{1}{0,017} \times 0,26^{2 / 3} \times 0,075^{1 / 2}$

$V=58,82 \times 0,407 \times 0,273$

$\mathrm{V}=6,54 \mathrm{~m} / \mathrm{detik}$

Nilai kekasaran Manning (n) dapat dilihat pada tabel 2.4

Menghitung debit aliran didalam saluran $\mathrm{Q}_{\mathrm{r}}$;

$$
\mathrm{Q}_{\mathrm{r}}=\mathrm{A} \times \mathrm{V}
$$

$\mathrm{Q}_{\mathrm{r}}=6,54 \times 0,518$

$\mathrm{Qr}_{\mathrm{r}}=3,387 \mathrm{~m}^{3} /$ detik

Analisis hidrologi dan hidrolika yang telah dilakukan didapatkan nilai debit rencana $\left(\mathrm{Q}_{\mathrm{p}}\right)=0,076 \mathrm{~m}^{3} /$ detik dan nilai debit aliran didalam saluran $\left(\mathrm{Q}_{\mathrm{r}}\right)=3,387 \mathrm{~m}^{3} /$ detik, sehingga dapat disimpulkan ketika nilai $\mathrm{Q}_{\mathrm{p}}<$ Qr $(0,076<3,387)$, maka tidak perlu dilakukan perencanaan ulang karena debit aliran didalam saluran sudah dapat ditampung oleh dimensi saluran yang ada di Permukiman Jakabaring Palembang. Tindakan yang perlu dilakukan saat ini untuk mencegah terjadinya banjir genangan yang terjadi adalah melakukan normalisasi saluran dengan cara menggali dan mengeluarkan sedimentasi yang ada didalam saluran tersebut. 
Diketahui Data:

Koefisien limpasan badan jalan $\left(\mathrm{C}_{1}\right) \quad=0,9$

Koefisien limpasan bahu jalan $\left(\mathrm{C}_{2}\right) \quad=0,4$

Koefisien limpasan perumahan $\left(\mathrm{C}_{3}\right) \quad=0,5$ Intensitas hujan rencana $(\mathrm{I})=105,99 \mathrm{~mm} / \mathrm{jam}$ Kemiringan dasar saluran dibuat sama dengan kemiringan memanjang jalan 0,003.

Dinding dan dasar saluran dibuat dari pasangan batu dengan nilai koefisien Manning 0,02.

Bentuk saluran segi empat dengan tinggi saluran direncanakan 1,25 kali lebar saluran.

Penyelesaian:

a. Menghitung debit limpasan

- Luas badan jalan $\left(\mathrm{A}_{1}\right)=150 \times 2,5=375 \mathrm{~m}^{2}$

- Luas bahu jalan $\left(\mathrm{A}_{2}\right)=150 \times 2,0=300 \mathrm{~m}^{2}$

- Luas Perumahan $\left(\mathrm{A}_{3}\right)=150 \times 30=4500 \mathrm{~m}^{2}$

Luas total area $(\mathrm{A})=375+300+4500$

$$
=5175 \mathrm{~m}^{2}
$$

Koefisen limpasan rata-rata ( C )

$$
\begin{aligned}
& C=\frac{C_{1} \cdot A_{1}+C_{2} \cdot A_{2}+C_{3} \cdot A_{3}}{A} \\
& C=\frac{0,9 \cdot 375+0,4 \cdot 300+0,5 \cdot 4500}{5175}=0,523
\end{aligned}
$$

Intensitas hujan rencana

(I) $=190 \mathrm{~mm} / \mathrm{jam}=2,94 \times 10^{-5} \mathrm{~m} / \mathrm{dt}$

Debit limpasan (Rumus Rasional)

$Q=C \cdot I \cdot A$

$$
\begin{aligned}
& =0,5 \times 2,94 \cdot 10^{-5} \times 5175 \\
& =0,076 \mathrm{~m}^{3} / \mathrm{dt}
\end{aligned}
$$

b. Menghitung dimensi saluran

$$
\begin{gathered}
V=\frac{1}{n} R^{\frac{2}{3}} S^{\frac{1}{2}} \\
\mathrm{Q}=\mathrm{A}_{\text {sal }} \times \mathrm{V}
\end{gathered}
$$

$$
\begin{aligned}
A_{\text {sal }} & =\frac{Q}{V}=\frac{Q}{\frac{1}{n} R^{\frac{2}{3}} S^{\frac{1}{2}}}=\frac{0,076}{\frac{1}{0,02} \cdot R^{\frac{2}{3}} \cdot 0,003^{\frac{1}{2}}}=\frac{0,028}{R^{\frac{2}{3}}} \\
A_{s a l} & =\frac{0,028}{\left(\frac{A_{s a l}}{P}\right)^{\frac{2}{3}}}
\end{aligned}
$$$$
b \cdot h=\frac{0,028}{\left(\frac{b \cdot h}{b+2 h}\right)^{\frac{2}{3}}}=
$$$$
b \cdot 1,25 b=\frac{0,028}{\left(\frac{b \cdot 1,25 b}{b+2 \cdot 1,25 b}\right)^{\frac{2}{3}}}
$$$$
1,25 b^{2}=\frac{0,028}{\left(\frac{1,25 b^{2}}{3,5 b}\right)^{\frac{2}{3}}}
$$$$
1,25 b^{2}=\frac{0,028}{(0,3571 b)^{\frac{2}{3}}}
$$$$
1,25 b^{2} \cdot 0,5034 \cdot b^{\frac{2}{3}}=0,028
$$$$
b^{\frac{8}{3}}=0,028 / 0,629=0,045
$$$$
b=0,311 \mathrm{~m}
$$$$
h=1,25 \cdot b=1,25 \cdot 0,311=0,389 \mathrm{~m}
$$

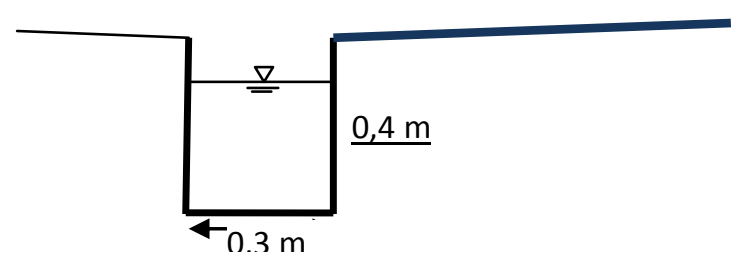

Gambar 4.1. Penampang melintang Asumsi 1

Menggunakan dimensi saluran lebar (b) $=0,3 \mathrm{~m}$ dan kedalaman air $(\mathrm{h})=0,4 \mathrm{~m}$, maka Asumsi pada gambar 1 sebagai perencanaan awal, namun untuk antisipasi, maka dimensi dapat dibuat asumsi tambahan sebesar $1,5 \mathrm{~h}$ dan $1,25 \mathrm{~b}$, sehingga dengan memperhitungkan faktor kemungkinan terjadi pengaliran yang maksimal saat hujan, maka dimensi dapat diperbesar seperti gambar 2 . 


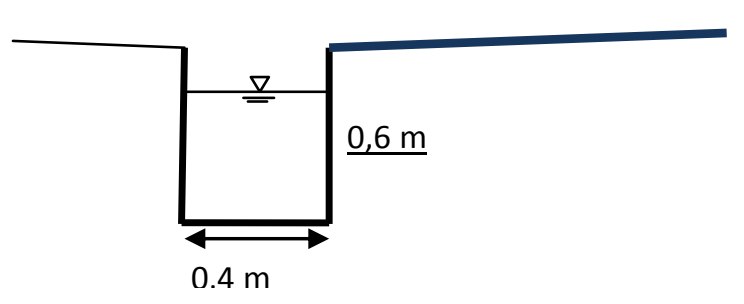

Gambar 4.1. Penampang melintang Asumsi 2

Berdasarkan hasil analisis data hidrologi dan hidrolika didapatkan hasil untuk nilai debit rencana $\left(Q_{p}\right)=0,076$ $\mathrm{m}^{3} /$ detik dan nilai debit aliran didalam saluran $\left(\mathrm{Q}_{\mathrm{r}}\right)=3,387 \mathrm{~m}^{3} /$ detik, sehingga dapat disimpulkan ketika nilai $\mathrm{Q}_{\mathrm{p}}<$ Qr,sehingga tidak perlu dilakukan perencanaan ulang karena debit aliran didalam saluran sudah dapat ditampung oleh dimensi saluran yang ada saat ini, dimana dimensi saluran drainase yang ada relatif sudah memenuhi standar, namun apabila akan diperbaiki atau direhab dapat dilakukan membuat saluran dengan dimensi hasil hitungan yang sama untuk kedua jenis saluran.

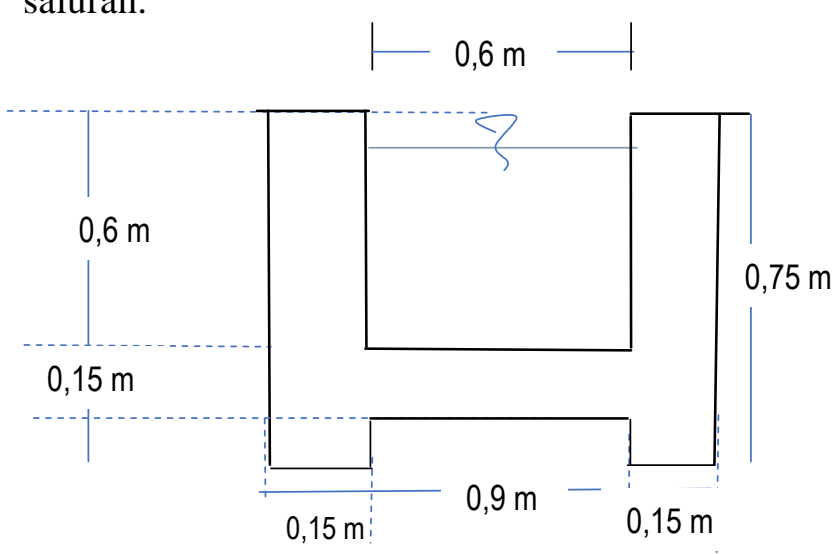

Gambar 4. Penampang Melintang Saluran

Perumahan Amin Mulia TOP dan Dekranasda

Dimensi saluran pada gambar 4,dianalogikan sama dan sesuai untuk saluran di kedua perumahan, namun untuk mencegah terjadinya banjir atau genangan dapat melakukan perbaikan atau pemeliharaan saluran, dengan cara pembersihan dari rumput/gulma, sampah dan sumbatan sumbatan lainnya. Selain itu, proses pemulihan jalur jalur pengaliran skala kecil yang selama ini mengaliran air limpasan permukaan jangan sampai rusak atau hilang karena alih fungsi.

\section{KESIMPILAN}

1. Dimensi saluran drainase yang ada saat ini sudah sesuai dengan topografi di wilayah Perumahan Top Amin Mulia dan Perumahan Dekranasda Jl. Kecamatan Jakabaring Kota Palembang. Hal ini, karena dari hasil perhitungan diperoleh debit rencana $\left(\mathrm{Q}_{\mathrm{p}}\right)=0,076 \mathrm{~m}^{3} /$ detik dan nilai debit aliran didalam saluran $(\mathrm{Qr})=3,387$ $\mathrm{m}^{3} /$ detik, sehingga dapat disimpulkan ketika nilai $\mathrm{Q}_{\mathrm{p}}<\mathrm{Q}_{\mathrm{r}}(0,076<3,387)$, maka artinya penampang saluran yang ada saat ini dapat menampung debit air hujan sehingga belum perlu dilakukanperencanaan ulang terhadap dimensi saluran.

2. Apabila akan direncanakan untuk memperbaiki saluran maka dimensi saluran drainase untuk kedua lokasi perumahan cukup menggunakan dimensi yang sama

3. Adapun penyebab terjadinya genangan atau banjir lingkup dikawasan tersebut adalah tertutupnya atau tersumbatnya saluran drainase oleh sedimen, rumput dan sampah.

\section{DAFTAR PUSTAKA}

Chow, Ven Te, Phd, (1992). Hidrolika Saluran Terbuka. Penerbit Erlangga. Jakarta.

Hasmar, Halim, (2012), Drainase Terapan. Penerbit UUI Press. Yogyakarta. Kusumawati, Enika.

Soehardjono, (1984), Drainase. Fakultas Teknik Universitas Brawijaya. Malang.

Subarkah, Iman, (1980), Hidrologi Untuk Perencanaan Bangunan Air. Penerbit Idea Dharma. Bandung.

Suripin,(2003), Sistem Drainase Perkotaan yang Berkelanjutan. Andi.Yogyakarta.

Suripin, (2004), Sistem Drainase Perkotaan yang Berkelanjutan. Andi Offset.Yogyakarta. 